\title{
The Implementation of Group Investigation with Audio Visual Learning Media to Improve Student`s Learning Achievement and Student's Attitude of Love the Homeland on Social Science Learning in Sambirejo 2 Junior High School
}

\author{
Andriati Rahayu', Sariyatun², Nunuk Suryani2 \\ 1Postgraduate Student of History Education Department, Faculty of Teacher Training and Education, Sebelas \\ Maret University, Surakarta, Indonesia \\ 2Lecturer of Postgraduate Program of Sebelas Maret University, Surakarta, Indonesia \\ 1andriati.rahayu66@yahoo.com,2sari_fkip_uns@yahoo.co.id,3nunuksuryani_uns@yahoo.com
}

$\begin{array}{ccc}\text { Received } & \text { Accepted } & \text { Published } \\ 07 / 09 / 2018 & 03 / 10 / 2017 & 31 / 12 / 2018\end{array}$

\begin{abstract}
The purpose of this research is to know the effectiveness of implementation of cooperative learning with group investigation and audiovisual media learning to improve student learning achievement and student's attitude of love the homeland at junior high school students. The classroom action research was used as research approach. The subjects of research subjects were teachers and 32 students of class VIIIA. The data were analyzed by interactive analysis technique and comparative descriptive analysis. The results of this study indicate the improvement of learning achievement with an average value of 70 in cycles I, 77 in cycles II, and 81.75 in cycle III. Meanwhile the attitude score for love of the homeland shows improvement with the average yield of 72 in cycles I, 82 in cycles II, and 85 in cycle 3 . Based on the results of the research, it can be concluded that the learning model for study Group Investigation with audiovisual learning media had proved to improve the learning achievement and attitude of love the homeland of student in the class VIIIA Sambirejo 2 State Junior High School.
\end{abstract}

Keywords: Group Investigation, audiovisual learning media, learning achievement, love the homeland

\begin{abstract}
Abstrak Tujuan dari penelitian ini adalah untuk mengetahui efektivitas dari implementasi Pembelajaran Kooperatif tipe group investigation dan media pembelajaran audio visual untuk meningkatkan prestasi belajar siswa dan perilaku cinta tanah air di SMP. Penelitian ini merupakan penelitian tindakan kelas. Subjek penelitian adalah guru dan 32 orang siswa kelas VIII A. Data analisis menggunakan teknik analisis interaktif dan analisis komparatif deksriptif. Hasil penelitian menunjukkan peningkatan hasil belajar rata-rata 70 pada siklus I, 77 pada siklus II, dan 81,75 pada siklus III. Adapun perilaku cinta tanah air menunjukkan peningkatan rata-rata 72 pada siklus I, 82 pada siklus II dan 85 pada siklus III. Berdasarkan hasil penelitian tersebut, dapat disimpulkan bahwa model pembelajaran group investigation dengan media pembelajaran audio visual dapat meningkatkan prestasi belajar dan perilaku cinta tanah air di Kelas VIII A SMP Negeri Sambirejo 2.
\end{abstract}

Kata kunci : group investigation, media pembelajaran audio visual, prestasi belajar, cinta tanah air 


\section{INTRODUCTION}

The low quality of learning process becomes an inevitable problem in the current purview of Indonesia education. In fact, generally, the level of Indonesia education is below the other country in the Southeast Asia area. This factual condition forces the Indonesia government to elevate the quality of Indonesia education. Some remarkable efforts of Indonesia government were done by curriculum benchmarking, the improvement of the teacher by education and training, and the provision of infrastructure to support the practice of education.

The quality of education cannot be separated from the learning process in the classroom. The common postulate is a high quality of learning process would produce higher learning achievement. High quality of learning process would foster the students to participate actively and creatively in the learning process, thus, they could achieve the maximum score of learning achievement. Education should generate a human who has intelligence, creative works, strong mentally, and a strong sensitivity to the social and environmental improvement problems. These learning outcomes are needed by the society to face the global challenge

Social science is one of the learning subjects, which is designed to provide a new social knowledge and experience to the student. By this knowledge and experience, the students could improve their socialization skills and the acknowledgement of the presence of others. Considering the importance of social science learning, then the teachers should be able to deliver the learning material effectively in order to achieve the objectives of learning.

Practically, in the implementation stage, the effectiveness of curriculum implementation is in the hand of the teacher that is supported by the students' participation in the classroom. Meanwhile, in the competitive globalized world, the process of education demand to generate a human who has intelligence, creative works, strong mentally, and a strong sensitivity to the social and environmental improvement problems. To realize these objectives, the educators should consider to the factual condition of the quality and quantity of Indonesia education that, unfortunately, is on the low grade. As a result, the student’s learning achievement in Indonesia is categorized on the low grade.

The implementation of Curriculum Based on Education Unit Level seems not running well. Social science learning is perceived by the students as difficult and uninterested learning subject. Such circumstances could be found in the national level as well as in the local level, for example, in Sambirejo 2 Junior High School in Sragen Regency, Central Java. 
Social science learning is ineffective because of some factors, for example the selection of learning method that have not been right and the lack of learning media that cause the monotonously learning process. Those factors, probably, affect the low level of student's learning achievement in Sambirejo 2 Junior High School. The lower level of student learning achievement could be seen on the score of the final exam in semester 1 during three periods of academic years.

Besides of learning achievement, the student's attitude to love their homeland as well as low. Globalization brings global values, which is some of them are not corresponding to the local values. Consequently, the student's attitude of love the homeland decreases significantly. The indication could be found in the student's awareness of the Indonesia and local cultures. The current phenomena of the Indonesian generation show that they rather praise the foreign culture than local culture. Others indication could be found in how the students participate in Monday Ceremony and how the students keep their social environment. Therefore, the cultivation of the attitude of love the homeland should be implemented to preserve the national identity and the student's attitude of love the homeland.

Other possible factors that affect the low level of the student's attitude of love the homeland is coming from the poor teachers learning skills. Teachers deliver the learning material by using monotone learning methods and media. In fact, generally, the teachers use conventional learning method, in which the teachers act as the center of the learning process. It means the teacher is still dominating in the learning process and they usually use speech-learning method. If it continues to happen, then, the learning process would become worse. The students could not express their ideas, notions, or argumentations, especially when they are facing a problem of learning. This condition aggravated by the practice of the learning model that's less involving the student's participation. Students are posited as the object of learning, thus, the learning process is held in one direction from teachers to students. Ironically, this learning approach is blunt the potency of students.

In order to maximize the student's potency, teachers should have creativity in forming the student's competencies. The learning process should attract the students to participate actively in exploring the scientific knowledge. In this framework, the teachers are obliged to enhance their competency to become the facilitator and learning partner for the students.

Based on this factual condition, it is necessary to solve the problem of student's low learning achievement. Some efforts, such as the development of learning model, should be 
done systematically in order to elevate the learning process and then improve the learning achievement. Therefore, the factual condition shows that the students are still posited as the object of learning. It means the existing learning process less include the student's roles and activities. Teachers should be able to change the learning paradigm that teachers are not the center of the learning process, but as a mentor, motivator, and facilitator. One of the learning models that emphasize on the group cooperation and supports the student's competency is a cooperative learning model. According to Isjoni (2013:12), cooperative learning is the learning models, which a number of students as a small group various skill level.

There are many models of cooperative learning that was developed by the educators and developers, one of them are group investigation. A group investigation learning model was developed as a complex learning method of learning group by Sharan and Sharan (1976) in order to foster the student`s critical thinking skill. The rationale of group investigation is philosophically based on the philosophical roots, ethic, and psychology since this century. The most influential figure of this learning approach is John Dewey. Dewey's perspectives toward a cooperative learning model become a prescription to solve complex problems in the daily life. According to Slavin (2014:215), the classroom is a site of creativity and cooperation, where the teacher and students work cooperatively in the learning process. The learning process is based on the mutual design of any experiences, capacities, and the needs of the students and teachers. Cooperative learning is the learning approach that focuses on the effectiveness of small group learning to work cooperatively and maximizes the learning condition to achieve the learning objectives (Sugiono, 2009:37).

According to Saputra, who cited by Sopiah Sangaji (2016), the objectives of group investigation learning model are to facilitate the students in understanding knowledge, has good interpersonal skills, effectively following the learning process within the learning group, has a discipline attitude, has commitment in social activities, learning independently, and appreciate the diversity. Group investigation learning model could not be implemented in learning environment that is not supported by interpersonal dialogues and social awareness. Cooperative communication and interaction among the students will achieve the best result if it is implemented in the small group that the exchanges between classmates and cooperative attitude can persist.

Group investigation learning model has some advantages. First, the students, who participate in group investigation, tend to be more active in the discussion and express their ideas. Second, the style of speech and cooperation among students could be observed. 
Third, the students could be more effective in learning cooperatively. Fourth, group investigation could force the student to be more active in the learning process. Fifth, group investigation permits the students to be more informal. Sixth, group investigation could improve the attitude and learning achievement of students. Sharan, who was cited by Sumarni (2012:127), state that beside of those advantages, the group investigation also has some weakness. First, group investigation is not supported by any particular research. Second, the learning projects in the learning group only include some active students. Third, group investigation, sometime, needs to be synchronized in different situation and condition. Fourth, the classroom condition is not always provides a good physical condition for the students. Fifth, the fruits of group investigation depend on the students` ability to lead the learning group or work independently.

According to Rusmam (2012: 221), the learning stages of group investigation contain six stages that comprise of: 1) identifying the learning topic and organizing the students into learning groups; 2) planning the learning tasks; 3) performing investigation; 4) preparing the learning report; 5) presenting the learning report; 6) evaluating the learning process. By group investigation, the students have opportunities to articulate their arguments, organize the information during the learning process, and improve their communication skills. Every member of a learning group has responsibilities to group successes and mastery the learning material that has been selected and studied.

In social science learning, learning media takes an important role. Learning media help teachers in describing and delivering information about the past events. According to Syaiful Bahri Djamarah dan Azwan Zain (2010:121), learning media is any learning tools and instrument that can be posited as a medium to transfer knowledge and achieve the learning objectives. Meanwhile, Nana Sudjana (2010:7) explains that learning media are a component of learning method that could improve the interaction among teacher, students, and their learning environment. Therefore, learning media is a learning tool that sustains the use of learning method. Through the use of learning media, the learning process as well as student learning achievement is expected to improve.

In the learning process, the learning media not merely has a function as a learning tool but also an instrument to achieve learning objectives. Every type of learning media has a characteristic, thus, it should be appropriate with the need and characteristic of the students. The learning media could be used to attract the student's attention in the classroom, particularly when the students feel bored. An appropriate learning process and learning media are expected to improve the student's nationalism. The definition of nationalism or love the homeland, according to Mahbubi (2012: 48), refers to ways of 
thinking, attitude, and show the loyalty, care, and appreciation to the language, culture, and the nation. Meanwhile, according to Arikunto (1966:12-13), in line with the concept of ngudi Hastuti, love of the homeland means love in the land where the people have lived from birth to the end of life. Santoso (2011) stated that love the homeland is the feeling of proud to be an Indonesian citizen with cultural treasure and its consequences that is becoming the good citizen, obey the order, norm, and law, and actively participates in defending the state.

The attitude of love the homeland should be imparted from the early age of the younger generation to build their pride. The manifestation of this attitude could be presented in their daily activity. Love the homeland is a way of thought and act, which is showing the loyalty, awareness, and high appreciation toward the language, environment, social environment, culture, economic, and politic. The implementation of Group Investigation with audiovisual learning could improve the student learning achievement as well as the students' feeling of love the homeland. Learning achievement is what students achieved, created, the results of work, the results of the fun that is obtained through work perseverance (Syaiful Bahri Djamarah: 2012). The definition of learning achievement is composed by particular activities that are learning process. According to Wina Sanjaya (2007:10), the learning is the proses of behavioral change because of experience and practice. From those descriptions, the authors extract a definition of learning achievement as the success level of students after taking the learning process about certain material, which are encompassing material mastery, emotional change or behavior change that can be measured by a particular test and embodied with a score or score.

The learning process of cooperative learning model and group investigation includes various social objectives and improve student achievements. Some experts argue that this model is excellent in helping students to understand difficult concepts. The developers of those models show that the reward structure in cooperative learning model has been successful to increase students' grades on academic learning and changes in norms related to learning outcomes. In line with this opinion, Isjoni (2012: 27) stated that in cooperative learning, although it covers a variety of social objectives but also improves student achievement and other important academic task tasks. The main idea of Group investigation learning is that students work together and are responsible for the progress of their peers because the cooperative approach emphasis on success and group goals can only be achieved if all group members achieve the goal or mastery of the material. As stated by Johnsen and Johnsen in Trianto (2012: 57) that the main objective of cooperative 
learning is to maximize student learning to improve academic achievement and understanding both individually and in groups.

In the cooperative learning model of group investigation, student achievement is known from the test, both in individuals and groups. The achievement test is done to know to what extent the students' understanding of learning materials after students are subject to action learning. Thus, in general, the implementation of group investigation in teaching and learning process can foster the responsibility of students so that they are directly involved actively in understanding a problem.

Based on research conducted in Bali, Group Investigation learning model is very effectively improved process skills and learning outcomes (Wiratama, I Gedhe, et. al; 2013). The results of research conducted by Sopiah Sangaji (2016) showed that Group Investigation model could improve students`achievement of vocational school students in Indonesia.

Based on the above explanation, the problems in this research are: (1) how is the Implementation of Group Investigation with audiovisual media on social science learning in Sambirejo 2 Junior High School, (2) how is the implementation of the learning process of Group Investigation with audiovisual media learning can improve the students' achievement of class VIII A Sambirejo 2 Junior High School in academic year of $2014 / 2015$, (3) how is the implementation of Group Investigation with audiovisual media learning can improve the students' attitude in love the homeland love of students in Sambirejo 2 Junior High School in academic year of 2014/2015.

In general, this research aims to 1) know the effectiveness of Implementation of Group Investigation with audiovisual media on social science learning in Sambirejo 2 Junior High School, 2) analyze the implementation of Group Investigation with audiovisual learning media to improve students` achievement of class VIII A in Sambirejo 2 Junior High School of academic year of 2014/2015, 3) know the implementation of Group Investigation learning with audiovisual media to improve the homeland love of the students of class VIII A Sambirejo 2 Junior High School of academic year of 2014/2015.

\section{METHOD}

The qualitative descriptive was used as the research method. The research cycles were started from planning, acting, observing, and reflecting (called cycle). This research is a classroom action research, which is a form of research conducted on the classroom situation with the aim of improving teacher performance and students` learning outcomes. The main design in this classroom action research has four stages: planning, action, 
observing, and reflecting. These four steps form a cycle that is performed several times according to the success rate of handling the selected problem to be handled. Action research is planned to be implemented in 3 cycles conducted by leading to the changes to be achieved that is to improve learning achievement and love attitude of the homeland of learners.

The research is carried out in a natural context that examines the factual problems in the learning process. It is intended to improve the student learning achievement and love of homeland class VIII-A Sambirejo 2 Junior High School. The used in the Group Investigation is intended to overcome student learning difficulties. The subjects of classroom action research are the teachers and 32 students of class VIII-A. The study was conducted from January to June 2015 in classroom VIII-A SMP Negeri 2 Sambirejo.

The data resources in this study were obtained from informants, which is consisting of social science teachers, peers as observers and resource persons, 2) places and events where research was conducted, 3) documents derived from data analysis, syllabus, lesson plan, and 4) books. Data collection techniques were conducted with observation, student's test, interview, documentation, and field notes.

The techniques of analysis data are observational persistence and triangulation. Persistence observational technique was done by observing carefully and meticulously on student activities during the learning process. Triangulation is a technique of validity checking by utilizing the instruments outside the data, for the purposes of checking or comparison of data (Sarwiji Suwandi, 2009: 60) The techniques analyze techniques that were used were interactive model analysis and comparative descriptive analysis. In the interactive model analysis, the three components of analysis of data from reduction, display, and the conclusion, were done in an interactive form with data collection as a cycle. In the comparative descriptive analysis technique of learning outcomes, this technique was done by comparing the learning outcomes in cycle I, cycle II, and cycle III with the aims to measure the changes of learning outcomes.

\section{RESULT AND DISCUSSION}

\section{The Effectiveness of the implementation of Group Investigation with Audiovisual Media Social Science Learning}

The implementation of Group Investigation with audiovisual media in social science learning had proved to make learning more fun and interesting, participatory and make students think critically. This classroom atmosphere makes students' understanding of the subject matter to be better. In addition, the students become more enthusiastic and 
understand the learning content in learning activities because with the proper application of media. Students able to appreciate and understand the material they are learning. It increased students' competence in terms of cognitive, affective and psychomotor.

Every learner has their own way of learning, thus, it is very important for them to know, excellence, uniqueness and lack of understanding of something. They need to find the right way to learn for themselves. As stated by Lavyanto Trimo (2006: 68), that every student has unique intelligence that can be identified and developed with patience. The background and the initial knowledge of the learner are very important to be understood by the educator in order to help advance the students. It is because knowledge is formed both individually and socially, so there are opportunities for group or cooperative learning to be developed.

That is in line with Sutarjo Adisusilo' argumentation (2013: 182), who stated that every student have a unique way to construct their own knowledge. Thus, the students are enabled to try a way of learning that suitable for themselves. Meanwhile, the educators need to try a variety of ways of learning model that are suitable for learners. In the classroom, students often bring a variety of concepts before the lesson begins. Cooperative learning methods contribute to the idea that every learner working together in learning and being accountable by others to make themselves as good as possible. The idea behind this kind of cooperative learning is that, if the students want their team to success, they should encourage their team members to be better. Cooperative learning is characterized by cooperative tasks and rewards. Students working in cooperative learning situations are encouraged to work together on a common task and they must be conditioned to finish together (Rusman, 2012: 208).

Slavin (2014: 4) examines that in the cooperative class, the students are expected to support, discuss, and argue to hone their current knowledge and close the gaps in their own understanding. Students in cooperative groups will learn from each other in order to ensure that everyone in the group has mastered the concept of thinking. Their success as a group depends on their ability to ensure that everyone has mastering key idea their mind. In cooperative learning, the student works together in cooperative atmosphere without being pressured. As Ibrahim argues that, the choice of this learning model is appropriate for understanding the difficult concepts because it enables students to increase their academic potential.

The use of learning media, which in this case is audio visuals, increases the student's participation in learning activities. This opinion is in line with Kowara and Halimah's 
argues that there is a correlation between the availability of learning media in schools and the success of student learning achievement (2008: 83).

The same argumentation also put forward by Nana Sudjana and Ahmad Rivai (2010: 7) that posits the function of learning media as the device to enhance the process of interaction between teachers, students, and their learning environment. Therefore, the learning media serve as a teaching tool that supports the teachers` teaching methods. The use of learning media is expected to enhance teaching and learning process, which the benefits of this process can enhance the quality of student learning outcomes. The use of instructional media, which is integrated into the cooperative and Group Investigation, can make learning more meaningful.

The successful implementation of Group Investigation with audiovisual media is supported by Ninik Sri Handayani's (2014) research, which stated that the implementation of the study group investigation model can improve students' learning outcomes.

\section{The Implementation of Group Investigation With Audiovisual Media in improving students`achievement}

The implementation of the Group Investigation learning model with audiovisual media was proved to improve students' achievement of class VII-IA Sambirejo 2 Junior High School. The improvement of student learning achievement can be seen from cycle I, cycle II, and cycle III, which can be seen in the table below.

Table 1. The comparison of students' achievement

\begin{tabular}{llcccc}
\hline No & Learning Achievement & Students' Scores & Cycle I & Cycle II & Cycle III \\
\hline 1 & The highest score & 78 & 92 & 96 & 100 \\
2 & The lowest score & 48 & 48 & 60 & 64 \\
3 & Average score & 64 & 70 & 77 & 81,75 \\
4 & Classical mastery & 28 & 47 & 59 & 88 \\
5 & Individual mastery & 9 & 15 & 19 & 28 \\
\hline
\end{tabular}


The application of the Group Investigation learning model with audiovisual media in social science learning shows the occurrence of the increase and improvement in learning achievement of students. This is in accordance with the opinion of Isjon (2013:27) that in cooperative learning through social goals cover a wide range but also improve the learning achievements of students as well as the duties of other important academic. Some experts argue that this model effective to help students understand a difficult concept.

According to Slavin in Rusman (2012: 220), the cooperative model of the investigative group is widely used in research and successfully demonstrates especially for the learning programs with specific task assignments. The improvement of academic achievement can occur because, in the model of Group Investigation, the student can exchange information and experience. Students can also express their opinions and ideas to process the information obtained and can improve communication skills, each member is responsible for the success of the group and the completeness of the material part that has been chosen which is the responsibility.

The use of learning media, in this case, which is integrated with the audiovisual learning and cooperative group learning, made the learning process more interesting and fun. Without the use of media of instruction, then the learning activities will be noticeably drier and less fun. The evaluation should be done to measure the progress of student's learning achievement. The assessment of cooperative learning model was done through an individual or group test and quiz. The assessment conducted by the teacher should encourage students to be more motivated in learning. This means that with the holding of such assessment work on the question, test or task must be to give encouragement to students to be more active in learning.

Learning achievement is the level of the learning progress that has been achieved by students in a learning program (Anwar, 2013:11). Based on that definition, it can be understood that learning achievement is the result of the learning activities. It can be said that the information of its contributions to the eligibility decision of education generally obtained from the measurement and assessment of education activities or specifically comes from learning achievement test.

This research indicates the improvement of students` learning achievement after the learning model was applied in the classroom. Established along the data that counts at the cycle I, the classical mastery learning of students only $47 \%$, then in cycle II the classical mastery raises to $59 \%$, and cycle III, the data presents the classical mastery reach $88 \%$. This score has beyond the object that has been determined is larger than or equal to $80 \%$.

The success of the implementation of the Group investigation in social skill learning is also supported by Ninik Sri Handayani's (2014) research that demonstrated the improvement of student learning achievement due to the implementation of the Group Investigation learning 
model. In addition, the research conducted by Wijayanti (2005) had explained that the application of the Group Investigation learning model could improve learning achievement. Other supported research comes from I Ktut Wiratama, (2010), which stated that the application of the Group Investigation learning model can improve learning achievement.

The betterment of learning achievement in Group Investigation was held by students exchange information and experiences in the group. This is in conformity with the Rusman's opinion (2012:219) that the application of the cooperative learning model gives students a keen opportunity to put forward their views and ideas to manipulate the data obtained as well as bettering the communication sciences. The members of the group had responsibility for the success of the group and the mastery level that has been selected.

\section{The Implementation of Group Investigation with Audiovisual Media in improving the} attitude of Love the homeland

The implementation of Group Investigation improved the level of student's attitude of love the homeland. The student's attitude can be observed from the table below.

Table 2. Comparison of the attitude of love the homeland

\begin{tabular}{|c|c|c|c|c|c|}
\hline No & $\begin{array}{l}\text { The attitude of love the } \\
\text { homeland }\end{array}$ & $\begin{array}{l}\text { Early } \\
\text { Score }\end{array}$ & Cycle I & Cycle II & Cycle III \\
\hline 1 & Total score & 2680 & 2880 & 3280 & 3409 \\
\hline 2 & Average score & 83,75 & 90 & 102,5 & 106,53 \\
\hline 3 & $\begin{array}{l}\text { Precentage of average score } \\
(\%)\end{array}$ & 67 & 72 & 82 & 85 \\
\hline 4 & $\begin{array}{l}\text { The number of students who } \\
\text { graduated }\end{array}$ & 10 & 16 & 22 & 29 \\
\hline 5 & Classical mastery (\%) & 31 & 50 & 69 & 90 \\
\hline
\end{tabular}

The learning objectives are, in fact, not merely impress the knowledge, but also transmit values, not just the learning the students to be bright but also gives the noble character and personality and a hard graphic symbol. Hence, in the learning of social science, broadly speaking, in the assessment of social skill learning is inseparable from the three aspects of the appraisal. The third aspect is the aspect of cognitive, affective, and psychomotor. This is in accordance with the theory of Bloom that stated there are three aspects of concern in putting together a learning goal, namely the realm of knowledge (cognitive), attitude (affective) realm and the realm of skills (psychomotor).

The historical learning needs to be learned with a proper model in order to build the knowledge. The implementation of cooperative learning model and Group Investigation creates an atmosphere of mutual cooperative that foster the atmosphere of mutual learning. The implementation of this learning model is able to arouse the interest and motivation of learning attitude. In addition, the implementation of cooperative learning model and Group Investigation 
also gave a great opportunity to build the appropriate knowledge from the experience that students have (Isjoni, 2013:7).

The above argument is supported by Sutarjo (2013:187), which stated that teaching is not moving the knowledge of educators to students but is an activity that allows students to build their own knowledge. The application of cooperative learning model and Group Investigation allows the learners to foster mutual challenge and work together in a cooperative atmosphere, thus, the student could understand the subject matter while enhancing attitudes love of the homeland.

Perceived from the insight that the teaching of history has a strategic position in national education, the basis of competency in social science learning is not merely serve to impart the history as a knowledge, but also the history of deed arouse protege or awaken consciousness of history ( Tsing Kartodirjo, 2014:280).

Focusing on the teaching of history and in order to raise the love of the homeland, enhance the love of the homeland, collective self-awareness, emerging problems that cover the "what" and "how" in conveying historical knowledge to the students. Thus, the two aspects of didactic history need to be popularized, that are learning methods and learning syllabus. Both these aspects have a reciprocal influence, in which are related to the age and level of education level of the students. These principles together with other didactic principle certainly apply here.

Props to facilitate teaching and learning such as audio visual, maps, drawings, observation places, visits to historical sites were used in the learning material about the Rengasdengklok event, the independence proclamation as well as meeting the PPKI. The students were so enthusiastic and excited to listen to the teacher and the learning material. The use of media enhances the participation of students in learning activities. This opinion is in line with Koswara, Natalie, and Halima (2008:83) that there is a correlation between the availability of media in schools with student learning success and improvement of student learning achievement.

The students' enthusiasm was proved by the score improvement in each cycle. In the cycle I, the percentage of students' attitude reach $50 \%$, then in cycle II rose to $69 \%$, and in cycle III was $90 \%$. This data shows that the attitude of love homeland beyond the desired target or greater than or equal to $80 \%$.

The improvement of the attitude of students love the motherland due understanding of history is already better. This could not separable from the application of the cooperative learning model of the type of audiovisual media with investigative group. The application of the model of teaching and the media can generate interest, attitude and motivation to learn as well as giving great opportunity to the students to play an active role in learning. Thus the application of the cooperative learning model of type Group Investigation with audio visual 
media make learning activities become more fun, fostering interest and attitude as well as make learning becomes more meaningful.

\section{CONCLUSION}

From the results of research can be drawn the conclusion. The implementation of cooperative learning model GI type (Group investigation) with the audio visual media in learning proven IPS can make learning more interesting, fun and learning activities in a more enthusiastic because the application of the right media they are more understood about the material being studied. Its implications will increase the competence of students both in terms of cognitive, psychomotor or affective.

The implementation of cooperative learning model GI type (Group investigation) and audiovisual media could improve the student' learning achievement classes VIII A Sambirejo 2 Junior High School. The learning achievements of students on initial conditions showed an average of 64.4 with $28 \%$ classical mastery. After done actions until the cycle III, learning achievement has increased with the average value reached 81.8 and classical mastery of $88 \%$. The implementation of cooperative learning model Group investigation and audiovisual media proved can improve the attitude of love of the homeland. According to the attitude of love of the fatherland on initial conditions only shows the percentage score an average of $67 \%$, whereas in the last cycle percentage average score increase which simply means that is becoming $90 \%$.

\section{REFERENCES}

Dewi, S.A.M.I.U, dkk. 2013. Pengaruh Model Pembelajaran Kooperatif Tipe Group Investigation (GI) dengan Media Photovoice Berbasis Lanskap Budaya Subak terhadap Perilaku Berkelompok Siswa SMP Amarawati Tampaksiring. Jurnal Universitas Mahasaraswati Denpasar.

Handayani, Ninik Sri. 2014. Penerapan Model Group Investigasi dengan Media Film pada Pembelajaran Sejarah untuk Meningkatkan Hasil Belajat Siswa dan Kesadaran Sejarah Siswa Kelas XII IPS 2 SMA Negeri 1 Bojonegoro Tahun Pelajaran 2013/2014. Tesis Program Studi Magister Pendidikan Sejarah Universitas Sebelas Maret.

Isjoni. 2013. Cooperative Learning. Bandung : Alfabeta

Lavyanto Trimo. 2006. Model Model Pembelajaran Inovatif. Bandung: Citra Praya.

Mahbubi. 2012. Pendidikan Karakter, Yogyakarta: Pustaka Ilmu Yogyakarta.

Nana Sudjana dan Ahmad Rivai. 2010. Media Pengajaran: Sinar Baru Algensindo.

Rusman. 2012. Model Model Pembelajaran. Jakarta: Raja Grafindo Persada.

Sangadji, Sopiah. Implementation of cooperative learning with group investigation model to improve learning Achievement of vocational school students in Indonesia. International Journal of Learning \& Development ISSN 2164-4063 2016, Vol. 6, No. 1. 
Trianto. 2012. Mendesain Model Pembelajaran Inovatif-Progresif. Jakarta : Kencana Perdana Medika.

Sartono Kartodirjo. 2014. Pendekatan Ilmu Sosial Dalam Metodologi Sejarah. Yogyakarta: Ombak.

Sartono Kartodirjo. 2014. Pemikiran dan Perkembangan Historiografi Indonesia. Yogyakarta: Ombak

Sumarni. 2012. Model Model Pembelajaran Geografi. Malang: Aditya Media.

Syaifudin Anwar. 2013. Tes Prestasi: Fungsi dan pengembangan prestasi belajar. Yogyakarta: Pustaka Pelajar.

Wijayanti, Lilis Siska. Perilaku Cinta Tanah Air Mahasiswa Jurusan PPKn Ditinjau dari Pemahaman Mata Kuliah Ilmu Kewarganegaraan.

Wijayanti, Wahyu, dkk. Pengaruh Model Pembelajaran Group Investigasi (GI) terhadap Kemampuan Berpikir Kritis Siswa Kelas X SMA Negeri 1 Gejayan Kabupaten Madiun". Jurusan Geografi, Fakultas Ilmu Sosial, Universitas Negeri Malang.

Wiratama, I Ketut, dkk. Pengaruh Model Pembelajaran Kooperatif Tipe Investigasi Kelompok (Group Investigation) terhadap Ketrampilan Proses dan Hasil Belajar Sains Siswa SMP. Jurnal Program Pascasarjana Universitas Pendidikan Ganesha Program Studi IPA Volume Volume 3 Tahun 2013.

Wina Sanjaya. 2007. Strategi Pembelajaran, Jakarta: Kencana Prenanda Medika.

Trianto. 2012. Mendesain Model Pembelajaran Inovatif-Progresif. Jakarta: Kencana Perdana Media Group. 